\title{
AALS TORTS AND COMPENSATION SYSTEMS SECTION William L. Prosser AWARd Bestowed UPON GUIDO CALABRESI
}

\author{
Catherine M. Sharkey*
}

The William L. Prosser award recognizes "outstanding contributions of law teachers in scholarship, teaching and service in ... torts and compensation systems." When Wex Malone bestowed the first Prosser Award upon Leon Green in 1974, he said it was "designed to recognize a lifetime of truly outstanding contribution to the world of torts." Subsequently, Fleming James, Wex Malone, Page Keeton, John Wade, and Willard Pedrick received the Prosser Award. Revived in 2008, recent recipients include Robert Rabin (2008), Dan Dobbs (2009), and Oscar Gray (2010).

It is my great honor and pleasure to present the 2011 Prosser Award to Guido Calabresi. Judge Calabresi was appointed to the U.S. Court of Appeals for the Second Circuit in 1994. Before that, he was Dean and Sterling Professor at Yale Law School, where he began teaching in 1959. He is now Sterling Professor Emeritus and Professorial Lecturer in Law at Yale.

Guido Calabresi was a pioneer in the economic analysis of law. His path-breaking 1970 book, The Cost of Accidents, ${ }^{1}$ was followed by three more books and over one hundred law review articles, including the venerated "Property Rules, Liability Rules and Inalienability: One View of the Cathedral." " He is also a revered teacher and mentor.

Indeed, at the ripe age of twenty-four when I entered Yale Law School, I thought it a form of "cosmic injustice" that I was not assigned Calabresi for Torts, as his work was largely responsible for my budding interest in law and economics. Higher forces aligned in time, as I was given the honor to serve as one of his law clerks from 1997-1998. Even during that term alone, Judge Calabresi continued to transform the Torts landscape, with cases such as Zuchowicz v. United States ${ }^{3}$ and Liriano v. Hobart Corp., ${ }^{4}$ now having entered the canon.

Judge Calabresi has been awarded some forty honorary degrees from universities in the United States and abroad. But the bestowal of the Prosser Award is especially meaningful, as his remarks that follow make abundantly clear.

* Professor of Law, New York University School of Law. Chair, AALS Torts and Compensation Systems Section, 2010-11. Law clerk to the Hon. Guido Calabresi, 1997-98. (1970).

1. Guido Calabresi, The Cost Of Accidents: A Legal And Economic Analysis

2. Guido Calabresi \& A. Douglas Melamed, Property Rules, Liability Rules and Inalienability: One View of the Cathedral, 85 HARV. L. REV. 1089 (1972).

3. Zuchowicz v. United States, 140 F.3d 381 (2d Cir. 1998).

4. Liriano v. Hobart Corp., 132 F.3d 124 (2d Cir. 1998). 
